\title{
Modelling of the canopy photosynthesis in intercropping with lettuce, rocket, radish, coriander and red beet
}

\section{Modelagem do dossel fotossintético em sistemas consorciados com alface, rúcula, rabanete, coentro e beterraba}

\author{
Laíza Gomes de Paiva ${ }^{1}$; Caciana Cavalcanti Costa ${ }^{2}$; Jerfferson Araujo Cavalcante ${ }^{3}$; Kilson Pinheiro Lopes ${ }^{4}$; \\ José Wilson da Silva Barbosa
}

\begin{abstract}
In the past years, many combinations of plants in intercropping have been demonstrating agronomic viability due to the increase of production per unity of area and greater use of natural resources. However, the knowledge and the proper choice of crops that will be part of the system are necessary to reach achievement, so that there is mutual interaction between them. The study had the purpose of evaluate the productivity of lettuce (Elba) intercropped with coriander (Verdão), rocket (Cultivada), beet (Early Wonder) or radish (Crimson Gigante). The experiment was conducted in the experimental area of the CCTA/UFCG, Pombal/PB, from September 2013 to July 2014. Nine treatments were assessed (4 intercropping and 5 monocultures), installed in randomized blocks with four replications. The amalgamation of lettuce with crops of coriander, rocket, radish or beet did not affected negatively its profitability. The intercropping of lettuce and beet presented the greater productive efficiency and efficient use of land, demonstrated by the increased production of both crops in this association.
\end{abstract}

Keywords: Lactuca sativa; Beta vulgaris; cultivate systems.

Resumo: Nos últimos anos muitas combinações de plantas em cultivo consorciado têm demonstrado viabilidade agronômica devido ao aumento de produção por unidade de área e maior aproveitamento de recursos naturais, no entanto, para que esse sistema alcance sucesso é necessário a escolha adequada das culturas que irão fazer parte do mesmo, de maneira que haja interação mútua entre elas. Com o objetivo de avaliar a produtividade da cultura da alface ('Elba') em consórcio com coentro ('Verdão'), rúcula ('Cultivada'), rabanete ('Crimson Gigante'), or beterraba ('Early Wonder') foi realizado o experimento na área experimental do CCTA/UFCG, em Pombal, PB, no período de setembro de 2013 a julho de 2014. Foram avaliados 9 tratamentos (4 cultivos consórcios e cinco monocultivos), instalados em blocos casualizados, com quatro repetições. A combinação da alface com as culturas do coentro, rúcula, rabanete ou beterraba não afetou negativamente a sua rentabilidade. O consórcio de alface e beterraba foi o que apresentou o seu maior rendimento produtivo e de uso eficiente da terra, demonstrado pelo aumento da produção de ambas as culturas, nesta associação.

Palavras-chave: Lactuca sativa; Beta vulgaris; sistemas de cultivo.

\footnotetext{
*Autor para correspondência

Recebido para publicação em 19/09/2016; aprovado em 25/11/2016

${ }^{1}$ Graduada em Agronomia, UFCG/CCTA/UAGRA, Pombal-PB, laizagomes@ outlook.com

${ }^{2}$ Professora Associada I, UFCG/CCTA/UAGRA, Pombal-PB, costacc@ ccta.ufcg.edu.br

${ }^{3}$ Doutorando em Ciência e Tecnologia de Sementes, FAEM/UFPel, Pelotas-RS, jerffeson_agronomo@hotmail.com

${ }^{4}$ Professor Associado I da UFCG/CCTA/UAGRA, Pombal-PB, kilsonlopes@ gmail.com

${ }^{5}$ Mestre em Engenharia Agrícola, UFCG, Pombal-PB, jwilsonematerpb@ hotmail.com
} 


\section{INTRODUCTION}

The intercropping is the simultaneous cultivation of two or more species with different cycles and vegetative architectures explored in the same area in the same period of time, and have not necessarily been sown at the same time (PINTO et al, 2011;. ALBUQUERQUE et al., 2012).

According to Souza e Resende (2006), the consortium of plants is presented as one of the most suitable to the practice of sustainable horticulture methods, with several advantages in the environmental aspect, productive and economical.

However, in general, the consortium system does not infer the use of technologies that seek maximum productivity. Accordingly, the determination of consortiums has received special attention, especially for the richness of interactions, providing ecological services that go beyond productivity (MONTEZANO; PEIL, 2006).

For success of this practice, it must be employed cultures with different cycle and height, species with slow development and wider spacing with other fast and small development, species of deep roots with shallow roots, species with sparse foliage with those bulkier, species that exhale odors and drive insects away, and in some cases, serving as tutor to another culture (FERREIRA et al., 2009).

The gains in global production obtained by the consortium can be associated with a series of interactions, to be known: a decreasing in the concentration of cultures making the establishment of pest arthropods, favoring interactions as beneficial mycorrhizal associations, inhibiting the growth of weeds, optimizing the use of water and fertilizer applied in the agro-ecosystem (GLIESSMAN, 2005; PENTEADO, 2009).

There are several possibilities for consortia of vegetable crops, among them, research has shown that red beet and lettuce (REIS et al., 2013), radish and lettuce (SUGASTI et al, 2013), lettuce and tomato (CECÍLIO FILHO et al., 2008), lettuce and rocket (COSTA et al., 2007), lettuce and coriander (SILVA, 2009), lettuce and pepper (PEREIRA, 2010), coriander and rocket (MOREIRA, 2011), and other consortiums have demonstrated promising results.

In this context, the aim of this work was to evaluate the productivity of crops in intercropping, in relation to its monoculture; To analyze which the interim culture that promotes less negative interference in the performance of the main crop (lettuce) and to verify the viability of consortiums as to the efficiency of efficient use of land.

\section{MATERIAL AND METHODS}

\section{Location and characterization of experimental area}

The experiment was conducted in the experimental area of the Centro de Ciências e Tecnologia Agroalimentar at the Universidade Federal de Campina Grande in Pombal, PB.

The city of Pombal-PB is located at geographic coordinates: Latitude $6^{\circ} 46^{\prime} 8$ South "and West Longitude $37^{\circ}$ $47^{\prime} 45^{\prime \prime}$ and has an average elevation of $250 \mathrm{~m}$, according to the Koppen climate classification, adapted to Brazil (Coelho \& Soncin, 1982), the climate of the region is the BSh type, i.e. hot and dry semi-arid region, showing a period of irregular rainfall between the months of February to June, and a dry spell between the months of July to January with average rainfall of $750 \mathrm{~mm}$ year $^{-1}$.

The average temperature is of $28^{\circ} \mathrm{C}$, with oscillating monthly average, between $25^{\circ} \mathrm{C}$ in the months of July/August, and $27^{\circ} \mathrm{C}$ in the months of January/February. The soil of the experimental area was classified as Luvissolo Crômico Órtico típico (BRASIL, 1972; SANTOS et al., 2013).

\section{Treatments and experimental design}

Nine treatments were evaluated (Table 1), corresponding to four crops members, resulting from the combination of crops of lettuce (main crop) with the cultures of the rocket, coriander, radish and red beet (interim crops) and five monoculture. The experiment was conducted in randomized blocks with four repetitions.

Table 1. Crop evaluated systems for crops of lettuce, arugula, cilantro, beets and radishes.

\begin{tabular}{cccc}
\hline & & Culture & \multirow{2}{*}{ System of Cultivation } \\
\cline { 2 - 3 } Treatments & Main & Interlayer & Member \\
$\mathbf{n}$ & Lettuce (present) & Rocket (Present) & Member \\
$\mathbf{2}$ & Lettuce (present) & Coriander (Present) & Member \\
$\mathbf{3}$ & Lettuce (present) & Radish (Present) & Member \\
$\mathbf{4}$ & Lettuce (present) & Red beet (Present) & Single \\
$\mathbf{5}$ & Lettuce (present) & Interlayer (Absent) & Single \\
$\mathbf{6}$ & Lettuce (absent) & Rocket (Present) & Single \\
$\mathbf{7}$ & Lettuce (absent) & Coriander (Present) & Single \\
$\mathbf{8}$ & Lettuce (absent) & Radish (Present) & Single \\
\hline
\end{tabular}

\section{Preparation of the soil of the experimental area}

Land preparation consisted of plowing and raising the beds and deploy the irrigation system. The area was structured, dividing it into four blocks each containing nine construction sites (parcels), each plot measuring $1.20 \mathrm{~m}$ wide by $2.0 \mathrm{~m}$ long and $20 \mathrm{~cm}$ high.
Then, the soil sampling was performed, which was sent for analysis in the Laboratory of Analysis of Water and Soil of the Federal Institute of Education, Science and Technology of Paraíba - Sousa Campus, whose results are in table 2.

According to the results from the soil analysis and following the recommendation of Cavalcanti et al. (2008), for planting fertilizing was considered the suggestion just for the 
main crop (lettuce). It was used in planting $30 \mathrm{~kg} \mathrm{ha}^{-1}$ of nitrogen, $60 \mathrm{~kg} \mathrm{ha}^{-1}$ of $\mathrm{P}_{2} \mathrm{O}_{5}$ and $60 \mathrm{~kg} \mathrm{ha}^{-1}$ of $\mathrm{K}_{2} \mathrm{O}$. The topdressings were performed separately for each culture according to the same authors. In effect, applied $40 \mathrm{~kg} \mathrm{ha}^{-1}$ of nitrogen, divided in twice on 10 and 20 days after transplanting of seedlings of lettuce and red beet (DAT) for coriander, rocket, radish and lettuce. In red beet cultivation was applied $40 \mathrm{~kg} \mathrm{ha}$ ${ }^{1}$ of urea and $30 \mathrm{~kg} \mathrm{ha}^{-1}$ of potassium, distributed into 25 and 45 DAT. In both cultures the used sources of $\mathrm{N}, \mathrm{P}_{2} \mathrm{O}_{5}$ and $\mathrm{K}_{2} \mathrm{O}$ were urea, superphosphate and potassium chloride, respectively.

Table 2. Chemical analysis of the soil of the experimental area of Pombal-PB.

\begin{tabular}{|c|c|}
\hline Variables & $\begin{array}{c}\text { Values } \\
\text { Obtained }\end{array}$ \\
\hline Potassium $\left(\mathrm{cmol}_{\mathrm{C}} \mathrm{dm}^{-3}\right)$ & 0,36 \\
\hline Sodium $\left(\mathrm{cmol}_{\mathrm{c}} \mathrm{dm}^{-3}\right)$ & 0,92 \\
\hline Calcium $\left(\mathrm{cmol}_{\mathrm{c}} \mathrm{dm}^{-3}\right)$ & 7,40 \\
\hline Magnesium $\left(\mathrm{cmol}_{\mathrm{c}} \mathrm{dm}^{-3}\right)$ & 6,10 \\
\hline Aluminum $\left(\mathrm{cmol}_{\mathrm{c}} \mathrm{dm}^{-3}\right)$ & 0,00 \\
\hline Hydrogen + aluminum $\left(\mathrm{cmol}_{\mathrm{c}} \mathrm{dm}^{-3}\right)$ & 0,00 \\
\hline Phosphorus (mg dm$\left.{ }^{-3}\right)$ & 327,00 \\
\hline Sum of Bases-SB $\left(\mathrm{cmol}_{\mathrm{c}} \mathrm{dm}^{-3}\right)$ & 14,80 \\
\hline Cationic exchange capacity-CTC $\left(\mathrm{cmol}_{\mathrm{c}} \mathrm{dm}^{-3}\right)$ & 14,80 \\
\hline Organic matter $\left(\mathrm{g} \mathrm{kg}^{-1}\right)$ & 11,30 \\
\hline $\mathrm{pH}$ in water $(1: 2.5)$ & 8,40 \\
\hline -V Bases saturation\% & 100,00 \\
\hline
\end{tabular}

\section{Conducting the experiment}

The intercropping, as well as the crop monocultures, were established by direct seeding of the coriander, rocket and radish, and transplanting of seedlings of lettuce and red beet. Crops of lettuce, coriander, red beet and radishes in monoculture had five rows of crops, with the exception of rocket that had six. In the intercropping of these crops with lettuce, they were deployed only in three lines.

In consortiums, crops were installed between the lines of the main culture, being transplanted in lettuce $0.30 \mathrm{~m}$ spacing between rows and $0.25 \mathrm{~m}$ between plants in both cropping systems. In single spacing between ranks was $0.25 \mathrm{~m}$ to the coriander, red beet and radishes and $0.20 \mathrm{~m}$ to rocket; Both the consortium as in monoculture, the spacing between plants was of $0.10 \mathrm{~m}$ for beets, 0.05 for rocket and $0.07 \mathrm{~m}$ for radish set after the thinning. In the consortium system and the single system, there was no control of spacing between plants for coriander, since the practice of pruning of plants for this culture is not commonplace in the region. Therefore, standardized up the amount of distributed seeds per metre of groove, following the recommendation of (SOUSA, 2008) which is $3 \mathrm{~g}$ per meter of groove, from the breaking of the diaquennium fruit, by crushing.

It was used seeds of the cultivars Elba, Cultivated, Green, Early Wonder and Giant Crimson, respectively for lettuce, rocket, coriander, red beet and radishes. The deployment of crops occurred in two ways: transplanting and direct seeding. The lettuce and beet crops performed the formation of seedlings from seed in expanded polystyrene tray of 288 cells, filled with commercial substrate Basaplant ${ }^{\circledR}$. The seedlings have grown in protected environment for thirty days and have been transplanted when presented five leaves. Other cultures were deployed by direct seeding in furrow in installments during the transplanting of lettuce, making ten days after sowing the thinning of rocket and radish.

After installation of the experiment were performed management of every culture. For weed control, where appropriate, there was weeding, since it was decided to not use any herbicide, manually being in beds and with the aid of hoes between them.

As for phytosanitary treatments, it was used pesticide Evidence ${ }^{\circledR}$ and comes from five days after the beginning of the experiment, at intervals of 10 days, considering the indication for the main crop.

The application of water was by irrigation method in equipment with flow of $60 \mathrm{~L} \mathrm{~h}^{-1}$, with a diameter of wetting of 4 $\mathrm{m}$ installed tall enough to properly irrigate all plants, but with careful not to cause the excess to one and disability for another.

The harvest of crops occurred when they had to be appropriate for trade, being harvested at once.

\section{Characteristics evaluated}

For the culture of lettuce were considered useful plants for evaluation of characteristics only plants, and how borders plants located at the beginning and end of each line of cultivation of the experimental unit. For the arugula, cilantro, radish and red beet were considered as useful plants, those located in the central metro monoculture and intercropping cultivation.

For the culture of lettuce were evaluated fresh and dry weight of the shoot, the weighing of fresh and dried basis (after drying in forced-air oven at $65{ }^{\circ} \mathrm{C}$ until present constant weight), respectively, and the diameter cross shoot. It was considered commercial lettuce with a mass greater than $100 \mathrm{~g}$. For coriander, rocket, radish and red beet were evaluated plant height, fresh and shoot dry (after drying in forced-air oven at 65 ${ }^{\circ} \mathrm{C}$ until present constant weight), respectively. For the coriander and rocket were considered as commercial plants taller than $10 \mathrm{~cm}$.

For the calculation of the efficient use of land (EUL), on the basis of the cropping systems, was used the formula proposed by Willey (1979): EUL $=(\mathrm{Yab} / \mathrm{Yaa})+(\mathrm{Yba} \mathrm{Ybb} /)$, where, Yab is the production of "culture" in partnership with the culture "b"; Yba is the production of culture " $b$ " in partnership with the culture "a"; Yaa is the production of "culture" in monoculture and Ybb is the production of culture "b" in monoculture. For calculation of indices were used crop production expressed in area $\left(\mathrm{t} \mathrm{ha}^{-1}\right)$, since there is difference to stand depending on the cultivation system.

\section{Statistical Analysis}

The statistical analyses were conducted by the ESTAT (BARBOSA, 1992). The obtained data was subjected to analysis of variance compared to Tukey test at $5 \%$ probability. For analysis of the results obtained on characteristics relating to 


\section{lettuce, was held with 4 treatments (3 consortia over RESULTS AND DISCUSSION} monoculture 1) and 4 repetitions.

For analysis of the intercropping data, analysis of variance was performed considering two treatments (1 consortium and monoculture 1) and 4 repetitions.

\section{Lettuce}

The summary of the analysis of variance for the data of plant height, fresh and dry mass of lettuce (Table 3 ) reveals that there was a significant effect of treatments on these parameters.

Table 3. Summary of the analysis of variance for the transverse diameter, fresh and dry mass of the aerial part of lettuce as a result of the different cropping systems.

\begin{tabular}{|c|c|c|c|c|}
\hline \multirow[b]{2}{*}{ Sources of variation } & \multirow[b]{2}{*}{ GL } & \multicolumn{3}{|c|}{ Average square } \\
\hline & & $\begin{array}{c}\text { Transverse diameter } \\
(\mathbf{c m})\end{array}$ & $\begin{array}{l}\text { Fresh weight } \\
\left(\text { g plant }^{-1}\right)\end{array}$ & $\begin{array}{c}\text { Dry weight } \\
\left.\text { (g plant }^{-1}\right)\end{array}$ \\
\hline Blocks & 3 & $17.0093^{\mathrm{NS}}$ & $2303.9082 *$ & $8.7063 * *$ \\
\hline Treatments & 4 & $9.7809^{\mathrm{NS}}$ & $3482.7369 *$ & $9.1229 * *$ \\
\hline Residue & 12 & 6.9234 & 660.9328 & 1.0351 \\
\hline Total & 19 & - & - & - \\
\hline Overall Average & - & 30.45 & 139.64 & 5.05 \\
\hline $\mathrm{CV}$ & - & 8.64 & 18.41 & 20.11 \\
\hline
\end{tabular}

(NS) not significant by $\mathrm{F}$ test. $(*)$, significant by $\mathrm{F}$ test

It was found that the average cross-sectional diameter (Table 4) presented no significant difference between the treatments, showing that the lettuce in all treatments had enough space for its development, and there is no competition for light. According to Oliveira et al. (2004), the proximity of intercropping cultures predisposes them to several interspecific competition, most commonly for light, water and nutrients, although they can also do it for oxygen, carbon dioxide and space.

The highest values of fresh and dry weight of lettuce were observed in intercropping of lettuce and red beet, but not statistically indistinguishable from intercropping with radish and lettuce monoculture (Table 4). Note that the beet and radish did not harm the performance of the main crop (lettuce). This may indicate that there was some competition exercised by the beet and radish for environmental resources like water, light and nutrients, and it was not enough to compromise the performance of the lettuce crop, or at least there was no coincidence in periods of high demands for these resources involved in the consortium (GRANGEIRO et al., 2011).
Cecilio Filho et al. (2007) evaluating the productivity of lettuce and radish intercropping observed that the fresh mass production of the aerial part of lettuce plants grown in intercropping did not differ from those given in monoculture when cultures were established on the same date. The intercropping of lettuce and coriander, and lettuce and rocket had the lowest values of fresh and dry mass for the aerial part of lettuce. Possibly, the presence of coriander negatively influenced the development of lettuce, causing some competition for environmental factors, since both produce in season only foliage cultivation and have similar cycles. However, the value of the efficient use of land index demonstrates efficient use of the area of intercropping, resulting in increased production of food per unit area (Table 4).

As can be seen in Table 4, the best use of available environmental factors occurred in the intercropping systems in relation to monoculture, since the efficient use of land index was greater than 1.0 , ranging from 1.74 to 2.27 , thus proving the efficiency more than $100 \%$ of the pools in relation to their monocultures.

Table 4. Average values of transverse diameter (TD), fresh weight of aerial part (FWAP), dry weight of the aerial part (DWAP) and index of efficient land use for lettuce according to the different cropping systems.

\begin{tabular}{ccccc}
\hline Treatments & TD $(\mathbf{c m})$ & FWAP $\left(\mathbf{g ~ p l a n t}^{-1}\right)$ & DWAP $\left(\mathbf{g ~ p l a n t}^{-1}\right)$ & Use of land index $^{-1}$ \\
\hline T1 & $27,74 \mathrm{a}$ & $113,58 \mathrm{~b}$ & $4,67 \mathrm{abc}$ & 1,74 \\
T2 & $30,78 \mathrm{a}$ & $111,93 \mathrm{~b}$ & $3,20 \mathrm{c}$ & 1,94 \\
T3 & $31,37 \mathrm{a}$ & $130,94 \mathrm{ab}$ & $4,21 \mathrm{bc}$ & 1,82 \\
T4 & $30,71 \mathrm{a}$ & $173,05 \mathrm{a}$ & $6,79 \mathrm{a}$ & 2.27 \\
T5 & $31,65 \mathrm{a}$ & $168,68 \mathrm{ab}$ & $6,41 \mathrm{ab}$ & 1,00 \\
\hline
\end{tabular}

T1: Intercropping of lettuce and rocket; T2: Intercropping of lettuce and coriander; T3: Intercropping of lettuce and radish; T4: Intercropping of lettuce and red beet and T5: lettuce monocropping. Averages followed by the same letter in the column do not differ by Tukey test at 5\% probability. 


\section{Rocket}

Regarding the height of plant results, fresh and dry mass of rocket (Table 4), it was observed that there was no significant difference between treatments for plant height, fresh and dry mass. Thus, these results are similar to those obtained by Oliveira et al. (2010), which evaluating the cultures of lettuce and rocket in intercropping system, under organic and mineral fertilizer, he found that the data of the dry mass and the rocket plant's height presented no significant difference in both cultivation systems; as a result, all consortia proved to be viable. Costa et al. (2007) evaluating the intercropping of curly lettuce groups, smooth, american, and rocket, found that there was no difference in dry weight values between the consortium established simultaneously and monoculture.

Table 5. Summary of variance analyzes regarding plant height, fresh weight and dry weight of shoots of rocket according to the different cropping systems

\begin{tabular}{|c|c|c|c|c|}
\hline \multirow[b]{2}{*}{ Source of variation } & \multirow[b]{2}{*}{ GL } & \multicolumn{3}{|c|}{ Average square } \\
\hline & & Plant height (cm) & $\begin{array}{l}\text { Fresh weight } \\
\qquad\left(\mathrm{g} \mathrm{m}^{-1}\right)\end{array}$ & $\begin{array}{c}\text { Dry weight } \\
\left(\mathrm{g} \mathrm{m}^{-1}\right)\end{array}$ \\
\hline Blocks & 3 & $1,2850^{\mathrm{NS}}$ & $7896,7109^{\mathrm{NS}}$ & $25,4364^{\mathrm{NS}}$ \\
\hline Treatments & 1 & $0,9800^{\mathrm{NS}}$ & $2298,0810^{\mathrm{NS}}$ & $41,8612^{\mathrm{NS}}$ \\
\hline Residue & 3 & 0,9133 & 6347,4727 & 65,9878 \\
\hline Total & 7 & - & - & - \\
\hline Overall average & - & 17,72 & 437,96 & 27,67 \\
\hline $\mathrm{CV}$ & - & 5,39 & 18,19 & 29,31 \\
\hline
\end{tabular}

(NS) not significant by F test

\section{Radish}

It was verified for plant height, fresh and dry mass of shoots of radish (Table 6) that there was no significant difference between treatments. According to Grangeiro et al. (2008), evaluating the growth and productivity of coriander and radish in function of intercropping during establishment times, observed that the radish plant height in intercropping was equal to monoculture when the sowing was held to zero days after sowing coriander, and dry mass of shoots of radish did not suffer significant interference between the evaluated factors. Moreover, Cecílio Filho et al. (2007) observed the productivity of radish monoculture was higher than that obtained in intercropping, and according to these authors this result was not due to the negative effect of lettuce on the radish, but on the stand differential between the treatments.

Table 6. Summary of variance analyzes regarding plant height, fresh weight and dry weight of shoots of radish according to the different cropping systems.

\begin{tabular}{|c|c|c|c|c|}
\hline \multirow[b]{2}{*}{ Sources of variation } & \multirow[b]{2}{*}{ GL } & \multicolumn{3}{|c|}{ Average square } \\
\hline & & Plant height $(\mathrm{cm})$ & $\begin{array}{l}\text { Fresh weight } \\
\qquad\left(\mathrm{g} \mathrm{m}^{-1}\right)\end{array}$ & $\begin{array}{c}\text { Dry weight } \\
\left(\mathrm{g} \mathrm{m}^{-1}\right)\end{array}$ \\
\hline Blocks & 3 & $28,8857^{\mathrm{NS}}$ & $23649,2112^{\mathrm{NS}}$ & $20,2095^{\mathrm{NS}}$ \\
\hline Treatments & 1 & $1,9701^{\mathrm{NS}}$ & $165,3471^{\mathrm{NS}}$ & $0,7750^{\mathrm{NS}}$ \\
\hline Residue & 3 & 3,3152 & 13042,1645 & 13,3432 \\
\hline Total & 7 & - & - & - \\
\hline Overall average & - & 19,97 & 348.63 & 19,22 \\
\hline $\mathrm{CV}$ & - & 9,12 & 32,76 & 19,00 \\
\hline
\end{tabular}

\section{Coriander}

In Table 7, it was found that for plant height, fresh and dry weight of shoots coriander the results showed no significant difference between treatments, possibly the architecture with the different heights of plants in study has been responsible for these results, i.e., there was no competition for space in diameter as seen by light or lettuce plants that already exhibited a similar height in both systems. Similar results were obtained by Oliveira et al. (2005), where evaluating the production and agro-economic value in the intercropping of coriander and lettuce cultivars observed that combinations showed different growth habit and temporal development, as expressed agronomic superior to monoculture. Moreover, Costa et al. (2009) observed that the total production and height of the coriander plant in intercropping with lettuce were significantly higher in intercropping system.

\section{Red Beet}

The analysis of variance for plant height, fresh and dry mass of red beet (Table 8) reveals that there was a significant effect of treatments on these parameters. 
Table 7. Summary of variance analyzes regarding plant height, fresh weight and dry weight of shoot coriander according to the different cropping systems

\begin{tabular}{lcccc}
\hline \multirow{2}{*}{ Sources of variation } & GL & Plant height $(\mathbf{c m})$ & $\begin{array}{c}\text { Fresh weight } \\
\left(\mathbf{g ~ m}^{\mathbf{- 1}}\right)\end{array}$ & $\begin{array}{c}\text { Dry weight } \\
\left(\mathbf{g ~ m}^{-\mathbf{1}}\right)\end{array}$ \\
\cline { 3 - 5 } & & $10,7833^{\mathrm{NS}}$ & $12295,8610^{\mathrm{NS}}$ & $23,7378^{\mathrm{NS}}$ \\
Blocks & 3 & $22,4450^{\mathrm{NS}}$ & $22130,9241^{\mathrm{NS}}$ & $18,9420^{\mathrm{NS}}$ \\
Treatments & 1 & 6,4283 & 7446,1061 & 46,2968 \\
Residue & 3 & - & - & - \\
Total & 7 & 25,05 & 402,63 & 35,15 \\
\hline Overall average & - & 10,12 & 21,43 & 19,35 \\
\hline CV & - & & & \\
\hline
\end{tabular}

(NS) not significant by F test

Table 8. Summary of variance analyzes regarding plant height, fresh weight and dry weight of shoot beet according to the different cropping systems

\begin{tabular}{|c|c|c|c|c|}
\hline \multirow[b]{2}{*}{ Sources of variation } & \multirow[b]{2}{*}{ GL } & \multicolumn{3}{|c|}{ Average square } \\
\hline & & Plant height $(\mathbf{c m})$ & $\begin{array}{c}\text { Fresh weight } \\
\quad\left(\mathrm{g} \mathrm{m}^{-1}\right) \\
\end{array}$ & $\begin{array}{c}\text { Dry weight } \\
\left(\mathrm{g} \mathrm{m}^{-1}\right) \\
\end{array}$ \\
\hline Blocks & 3 & $20,6889 *$ & $1399,0761^{\mathrm{NS}}$ & $0,7697^{\mathrm{NS}}$ \\
\hline Treatments & 1 & $15,2124^{\mathrm{NS}}$ & $62838,6701 * *$ & $204,6265^{* *}$ \\
\hline Residue & 3 & 2,0839 & 3181,0315 & 1,1892 \\
\hline Total & 7 & - & - & - \\
\hline Overall average & - & 17,38 & 551,45 & 25,39 \\
\hline $\mathrm{CV}$ & - & 8,30 & 10,23 & 4,30 \\
\hline
\end{tabular}

(NS) not significant by F test. (*), Significant by F test

In Table 9 the values of fresh and dry shoots of beet when intercropping with lettuce were higher compared to monoculture. Possibly the microclimate created between plants in the intercropping favored the development of beet, with no competition for light and space in the consortia, demonstrating interaction between cultures, given that the lettuce and red beet consortium was the best because both lettuce and red beet indicated good yields and the efficient use of land index these treatment was the one with the highest value (2.27). According to Rezende et al. (2006), the spatial and temporal complementarity between intercropped species is related to differences in architecture, cycle and existing size between them. Grangeiro et al. (2007), evaluating the productivity of red beet and rocket depending on planting season in monoculture and intercropping, found lower beet yield in intercropping system, although the rocket present short cycle, but with rapid initial growth, it was promoted greater competition mainly interspecific by light when the sowing red beet and rocket were held simultaneously.

Table 9. Average values of plant height (PH), fresh weight of aerial part (FWAP) and dry matter of the aerial part (DMAP) beet according to the different cropping systems

\begin{tabular}{cccc}
\hline Treatments & PH $(\mathbf{c m})$ & FWAP $\left(\mathbf{g ~ m}^{-1}\right)$ & DMAP $\left(\mathbf{g ~ m}^{-1}\right)$ \\
\hline T1 & $18,78 \mathrm{a}$ & $640,07 \mathrm{a}$ & $30,44 \mathrm{a}$ \\
$\mathrm{T} 2$ & $15,99 \mathrm{a}$ & $462,82 \mathrm{~b}$ & $20,33 \mathrm{~b}$ \\
\hline
\end{tabular}

T1: Consortium lettuce and red beet; T2: red beet monocropping. Means followed by the same letter in the column do not differ by Tukey test at $5 \%$ probability.

\section{CONCLUSION}

The combination of lettuce (main crop) with coriander, rocket, radishes and red beet did not negatively affect the production yield of lettuce.

The effective use of land index has shown that the intercropping were viable in the efficient use of land, where lettuce and beets showed their highest yield.

\section{ACKNOWLEDGEMENTS}

The support of $\mathrm{CNPq}$, the National Council for Scientific and Technological Development - Brazil (PIBIC / $\mathrm{CNPq}$ / UFCG) for the scholarship granted. 


\section{REFERENCES}

ALBUQUERQUE, J. A. A.; SEDIYAMA, T.; ALVES, J. M. A.; SILVA, A. A.; UCHÔA, S. C. P. Cultivo de mandioca e feijão em sistemas consorciados realizado em Coimbra, Minas Gerais, Brasil. Revista Ciência Agronômica. Fortaleza, v. 43, n. 3, p. 532-538, 2012.

BARBOSA, J. C.; MALHEIROS, E.B.; BANZATTO, D.A. ESTAT: Um sistema de análises estatísticas de ensaios agronômicos. Jaboticabal: Unesp, 1992. Versão 2.0.

BRASIL, MAPA. Levantamento Exploratório: Reconhecimento de Solos do Estado da Paraíba. Rio de Janeiro; Equipe de Pedologia e Fertilidade do Solo (MA), 670p. 1972.

CAVALCANTI, F. J. A.; SANTOS, J. C. P.; PEREIRA, J. R.; LEITE, J. P.; SILVA, M. C. L.; FREIRE, F. J.; SILVA, D. J.; SOUSA, A. R.; MESSIAS, A. S.; FARIA, C. M. B.; BURGOS, N.; LIMA JÚNIOR, M. A.; GOMES, R. V.; CAVALCANTI, A.C.; LIMA, J. F. W. F. Recomendação de adubação para o estado de Pernambuco. Recife: IPA. 2008. 199p. $\quad\left(2^{\mathrm{a}}\right.$ aproximação).

CECILIO FILHO, A. B.; REZENDE, B. L. A; CANATO, G. H. D. Produtividade de alface e rabanete em cultivo consorciado estabelecido em diferentes épocas e espaçamentos entre linhas. Horticultura Brasileira. Brasília, v. 25, n. 1, p. 15-19, 2007.

CECÍlIO FILHO, A. B.; REZENDE, B. L. A.; BARBOSA, J. C.; FELTRIM AL; SILVA, G. S.; GRANGEIRO, L. C. Interação entre alface e tomateiro consorciados em ambiente protegido, em diferentes épocas. Horticultura Brasileira. Brasília, v. 26, n. 2, p. 158-164, 2008

COELHO, M. A.; SONCIN, N. B. Geografia do Brasil. São Paulo: Moderna, 1982. 368 p.

COSTA C.C; CECÍLIO FILHO A.B; REZENDE B.L.A; BARBOSA J.C; GRANGEIRO L.C, Viabilidade agronômica do consórcio de alface e rúcula, em duas épocas de cultivo, Horticultura brasileira. Brasília, v. 25, n. 1, p. 34-40, 2007.

COSTA, C. C.; SILVA, A. S.; FERREIRA, E. F.; MONTEIRO, R. F.; CECÍlIO FILHO, A. B. Avaliação do efeito das culturas intercalares no cultivo consorciado de alface. Horticultura Brasileira. Brasília, V. 27, n. 2 (Suplemento - CD Rom). 2009.

FERREIRA, R. M. A.; AROUCHA, E. M, M.; MESQUITA, H. C.; FREITAS, F. C. L.; NUNES, G. H. S. Qualidade PósColheita de Cenoura Durante o Desenvolvimento em Monocultivo e Consorciada com Rabanete. Revista Ciência Agronômica. Fortaleza, v. 42, n. 2, p. 423-428, 2009.

GLIESSMAN, S. R. Agroecologia: processos ecológicos em agricultura sustentável. 3 ed. Porto Alegre, UFRGS, 2005. $653 \mathrm{p}$.
GRANGEIRO, L. C.; NEGREIROS, M. Z.; SANTOS, A. P.; COSTA, L. M.; SILVA, A. R. C.; LUCENA, R. R. M. Crescimento e produtividade de coentro e rabanete em função da época de estabelecimento do consórcio. Revista Ciência e Agrotecnologia, Lavras, v. 32, n. 1, p. 55-60, 2008.

GRANGEIRO, L. C.; BEZERRA NETO, F. B.; NEGREIROS, M. Z.; CECÍlIO FILHO, A. B.; CALDAS, A. V. C.; COSTA, N. L. Produtividade da beterraba e rúcula em função da época de plantio em monocultivo e consórcio. Horticultura Brasileira. Brasília, v. 25, n. 4, p.577-581, 2007.

GRANGEIRO, L. C.; SANTOS, A. P.; FREITAS, F. C. L.; SIMÃO, L. M. C.; BEZERRA NETO, F. B. Avaliação agroeconômica das culturas da beterraba e coentro em função da época de estabelecimento do consórcio. Revista Ciência Agronômica. Fortaleza, v. 42, n. 1, p. 242-248, 2011.

MOREIRA, J. N. Consorciação de rúcula e coentro adubada com espécie espontânea sucedida pelo cultivo de rabanete. Tese (Doutorado em Fitotecnia), Universidade Federal Rural do Semi-Árido, Mossoró, RN. 2011. $116 f$.

MONTEZANO, E. M.; PEIL, R. M. N. Sistema de consórcio na produção de hortaliças. Revista Brasileira de agrociência. Pelotas, v. 12, n. 2, p.129-132, 2006.

OLIVEIRA, E. Q.; BEZERRA NETO, F. B.; NEGREIROS, M. Z.; BARROS JUNIOR, A. P.; FREITAS, K. K. C.; SILVEIRA, L. M.; LIMA, J. S. S. Desempenho agroeconômico do bicultivo de alface em sistema solteiro e consorciado com cenoura. Horticultura Brasileira. Brasília, v. 22, n. 4, p. 712-717, 2004.

OLIVEIRA, E. Q.; BEZERRA NETO, F. B.; NEGREIROS, M. Z.; BARROS JÚNIOR, A. P.; FREITAS, K. K. C.; SILVEIRA, L. M.; LIMA, J. S. S.; Produção e valor agroeconômico no consórcio entre cultivares de coentro e de alface. Horticultura Brasileira, Brasília, v. 23, n. 2, p. 285-289, 2005.

OLIVEIRA, E. Q.; SOUZA, R. J.; CRUZ, M. C. M.; MARQUES, V. B.; FRANÇA, A. C. Produtividade de alface e rúcula, em sistema consorciado, sob adubação orgânica e mineral. Horticultura Brasileira. Brasília, v. 28, n. 1, p. 36-40, 2010 .

PENTEADO, S. R. Manual prático de agricultura orgânica fundamentos e técnicas. Campinas, SP, edição autônoma. 2009. 216p.

PEREIRA, E. D. Estudo da viabilidade agronômica dos policultivos do pimentão com as culturas do coentro, alface e cebolinha. Monografia (Graduação em Agronomia), Universidade Federal de Campina Grande, Pombal, PB. 2010. $37 f$.

PINTO, C. M.; SIZENANDO FILHO, F. A.; CYSNE, J. R. B.; PITOMBEIRA, J. B. Produtividade e índices de competição da mamona consorciada com gergelim, algodão, milho e feijão caupi. Revista Verde de Agroecologia e Desenvolvimento Sustentável. Mossoró, v.6, n.2, p.75-85, 2011. 
REIS, J. M. R.; RODRIGUES, J. F.; REIS, M. A. Adubação em consórcio de beterraba com alface. Enciclopédia Biosfera. Goiânia, v. 9, n.17, p.41, 2013.

REZENDE, B. L. A.; CECÍLIO FILHO, A. B.; FELTRIM, A. L.; COSTA, C. C.; BARBOSA, J. C. Viabilidade da consorciação de pimentão com repolho, rúcula, alface e rabanete. Horticultura Brasileira. Brasília, v.24, n. 1, p. 36-41, 2006.

SANTOS, H. G. et al. Sistema Brasileiro de Classificação de Solos. 3. ed. Rio de Janeiro: Embrapa, 2013. 353 p.

SILVA, A. S. Desempenho das culturas alface, coentro e rúcula em consórcio, no município de Pombal-PB. Monografia de conclusão de Curso (Graduação em Agronomia), Universidade Federal de Campina Grande, Pombal, PB. 2009. $28 \mathrm{p}$.

SOUSA, V. L. B. Quebra do Fruto-Semente (Diaquênio) a Densidade de Semeadura na Cultura do Coentro. Monografia de conclusão de curso. Pombal: CCTA/UFCG, p..iI, 2008.

SOUZA, J. L. de.; RESENDE, P. Manual de Horticultura Orgânica. Viçosa, MG. ed. 2, 2006. 843p.

SUGASTI, J. B.; JUNQUEIRA, A. M. R.; SABOYA, P. A. Consórcio de rabanete, alface e quiabo e seu efeito sobre as características agronômicas das culturas, produção e índice de equivalência de área. Revista Brasileira de Agroecologia. v. 8, n. 2, p. 214-225, 2013.

WILLY, R. S. Intercropping - its importance and research needs. Part 1. Competition and yield advantages. Field Crop Abstracts. b. 32, p 1-10, 1979. 